\author{
Ольга Титюк, \\ Володимир Грубий, \\ Ярослав Степанюк, \\ Олександр Яригін
}

\title{
Просторова реконструкція нюхових структур Lacerta viridis за допомогою комп'ютерного моделювання
}

\begin{abstract}
Описано приклад створення просторової реконструкції структур нюхового аналізатора (носової порожнини, вомероназального органа, нюхових нервів, нюхових цибулин) ембріона ящірки зеленої Lacerta viridis 34-ї стадії розвитку. Побудову просторової моделі проведено в програмі Amira 5.0.

Ключові слова: ембріон, просторова реконструкція, нюховий епітелій, вомероназальний орган.
\end{abstract}

Постановка наукової проблеми та її значення. Більшість сучасних морфологічних досліджень неможливі без створення просторових реконструкцій структур. Перші 3 них мали вигляд рисунків, які створювалися на основі перегляду та аналізу серійних зрізів. Метод пластичної реконструкції грунтується на створенні тривимірних моделей на основі воскових пластинок. Створення таких реконструкцій було не зовсім точним і вимагало великих затрат часу. На сьогодні в медицині та біології популярні методи комп'ютерної та магнітно-резонансної томографії, проте вони призначені для дослідження досить великих об'єктів. У біології часто постає потреба об'ємних реконструкцій дрібних об'єктів, таких як ембріональні структури й органи. Одним зі способів розв'язання цієї проблеми $є$ побудова 3D-моделей за серійними зрізами за допомогою програми Amira for microscopy. Ïї застосування під час дослідження морфогенезу окремих структур особливо актуальне, оскільки більшість структур змінюють форму, розміри та топографію, що важко виявити й описати при перегляді тотальних мікропрепаратів. Створені реконструкції можуть слугувати наочністю в наукових статтях та монографіях. Крім того, Аmira є порівняно простою в роботі й не потребує спеціальних знань і навичок. Тому метод 3D-реконструкцій усе більше застосовується морфологами.

Аналіз досліджень проблеми. Незважаючи на те, що існує чимало прикладів просторової 3Dреконструкції різних структур $[1 ; 2 ; 3 ; 5 ; 6 ; 11]$, лише незначна їх частина стосується опису методики створення 3D-реконструкції [9]. Зазвичай дослідники для кожного етапу побудови реконструкцій використовують окремі програми, що створює певні незручності. Комп’ютерне моделювання за допомогою Amira for microscopy є простішим і якіснішим методом. У літературі недостатньо відомостей про методику створення просторових реконструкцій у цій програмі.

Мета дослідження - створення тривимірної моделі нюхових структур за допомогою програми Amira for microscopy на прикладі ембріона ящірки зеленої.

Виклад основного матеріалу й обтрунтування отриманих результатів дослідження. Матеріали та методи дослідження. Як модельний об'єкт дослідження нами вибрано ембріон 34-ї стадії розвитку ящірки зеленої Lacerta viridis (Laurenti, 1768). Стадії онтогенезу визначали за таблицями нормального розвитку для Lacerta vivipara [10]. Фіксацію, промивку, дегідратацію, заливку в парафін та виготовлення зрізів товщиною 5-7 мкм у поперечній площині (рис. 1) проводили відповідно до стандартних гістологічних методик [4].

Забарвлення тотальних мікропрепаратів здійснювали альціановим синім із подальшим дофарбовуванням гематоксилін-еозином за Стідменом [12]. Фотографування серійних зрізів виконували на мікроскопі Zeiss Axio Imager M1 та за допомогою програмного забезпечення Zeiss Axio Vision v. 4.63 у центрі колективного користування унікальним обладнанням при Інституті зоології ім. І. І. Шмальгаузена НАН України. Тривимірні моделі створено за програмою Amira for microscopy.

Морфологія нюхового аналізатора. Відомо, що периферичний відділ нюхового аналізатора рептилій морфологічно розділений на основну та додаткову нюхові системи. Перша представлена нюховим епітелієм носової порожнини, а друга - вомероназальним органом. Для реконструкції вибрано структури нюхового аналізатора (носову порожнину, вомероназальний орган, нюхові нерви та нюхові цибулини). Морфогенез цих структур нами детально описано на прикладі ящірки прудкої Lacerta agilis (Linnaeus, 1758) [7; 8]. Оскільки нюхові структури на 34-й стадії розвитку ящірки зеленої мають морфологічні особливості, то коротко їх опишемо.

( Титюк О., Грубий В., Степанюк Я., Яригін О., 2015 


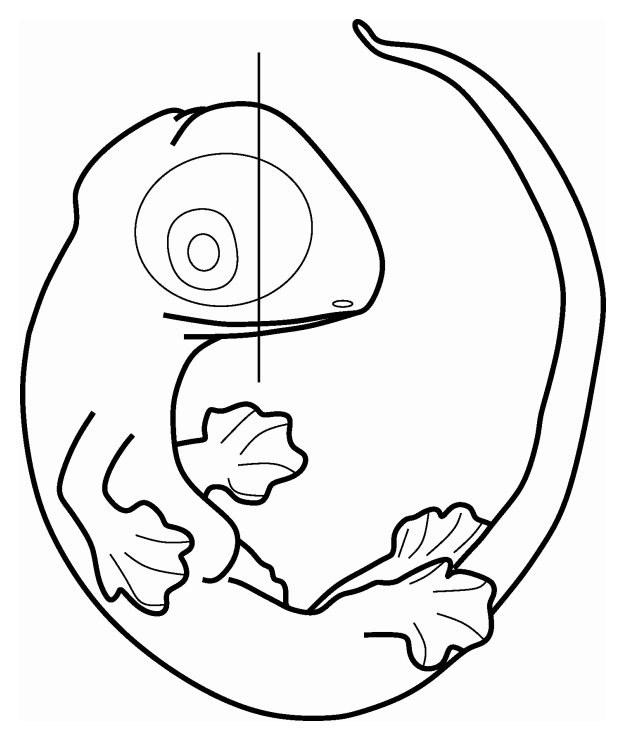

Рис. 1. Схема отримання серійних зрізів ембріона L. viridis 34-ї стадї̈ розвитку

Зачатки зовнішніх ніздрів розміщуються вентролатерально в ростральній частині голови. Вузький присінок переходить у серпоподібну носову порожнину, яка вентрокаудально через хоани сполучена $з$ ротовою порожниною. Вентральна стінка носової порожнини має випинання - носову раковину (рис. 2). Нюховий епітелій вистилає майже всю поверхню носової порожнини. Вомероназальний орган ще не відділений від носової порожнини. Він міститься вентрально між носовою перегородкою та носовою порожниною. Вентральна стінка вомероназального органа має випинання вомероназальну раковину. На цій стадії вомероназальний орган латерально сполучений із носовою порожниною, а вентрально - із зачатком ротової порожнини (рис. 2; 4). Медіальна й дорсальна стінки вомероназального органа вистелені нюховим епітелієм

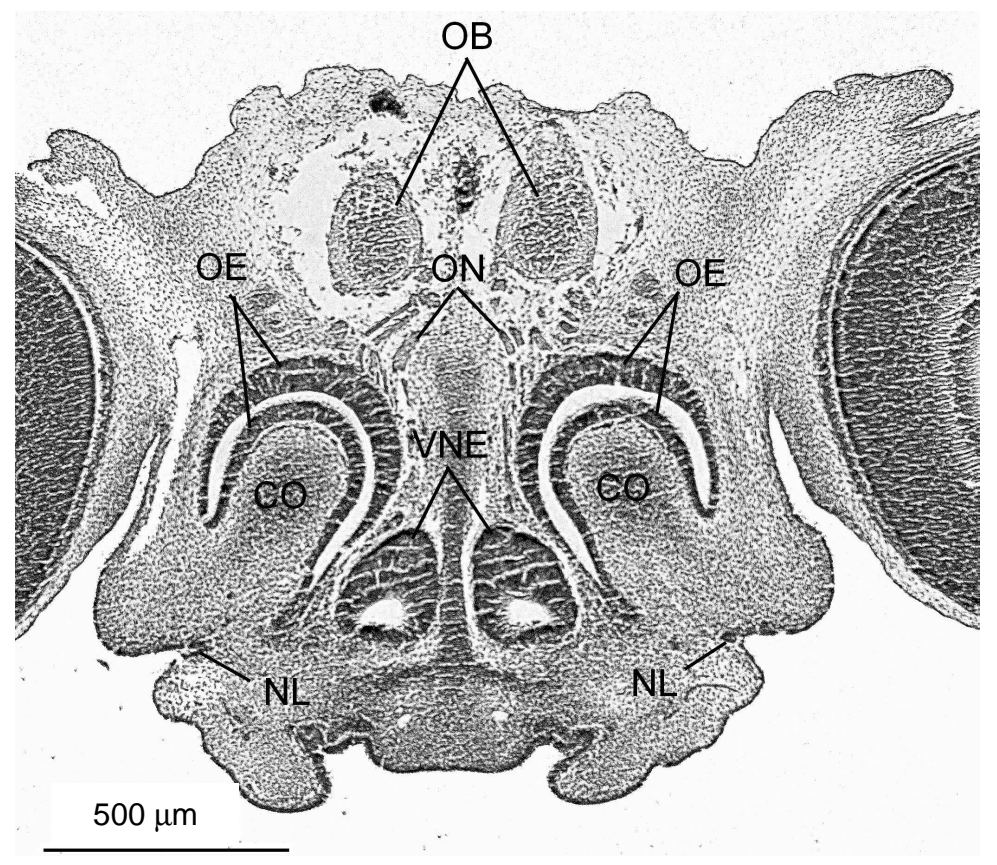

Рис. 2. Поперечний зріз через нюхові структури ембріона L. viridis 34-ї стадіï розвитку (барвник: альиіановий синій та гематоксилін-еозин):

$\mathrm{OE}$ - нюховий епітелій; ОВ - нюхові цибулини; ON - волокна нюхових нервів; CO - носова раковина; $\mathrm{NL}$ - зачаток носослізної протоки; VNE - вомероназальний епітелій. 
Волокна нюхового та вомероназального нервів відходять від дорсальної стінку носової порожнини та вомероназального органа й ростровентрально входять у нюхові цибулини (рис. 2).

Створення просторової реконструкції нюхових структур. Носова порожнина, вомероназальний орган, нюхові нерви та нюхові цибулини - протяжні структурами, що мають відносно складну форму (рис. 3). Для кращого сприйняття об'ємності структур на основі мікрофотографій серії послідовних гістологічних зрізів створюємо просторову реконструкцію в програмі Amira. Робота в ній складається 3 підготовки мікрофотографій серійних зрізів, вирівнювання досліджуваних структур і виділення контурів досліджуваних структур. Підготовка мікрофотографій уключає контрастування та зменшення розмірів зображень. Усі ці кроки можна виконати в будь-якому графічному редакторі. Готові фотографії завантажуємо в програму Аmira. У ній проводимо вирівнювання зображень структур, від якого залежить правильне створення каркасу моделі. Вирівнювання потрібно здійснювати відносно структур, які не змінюють своєї форми під час різки на мікротомі. Після вирівнювання розпочинають виділення контурів досліджуваних структур і формують каркас тривимірної моделі. Для цього в програмі міститься низка інструментів, найпростіший із яких - пензлик, що дає змогу просто замалювати потрібну структуру й перетворити ії у виділену ділянку.

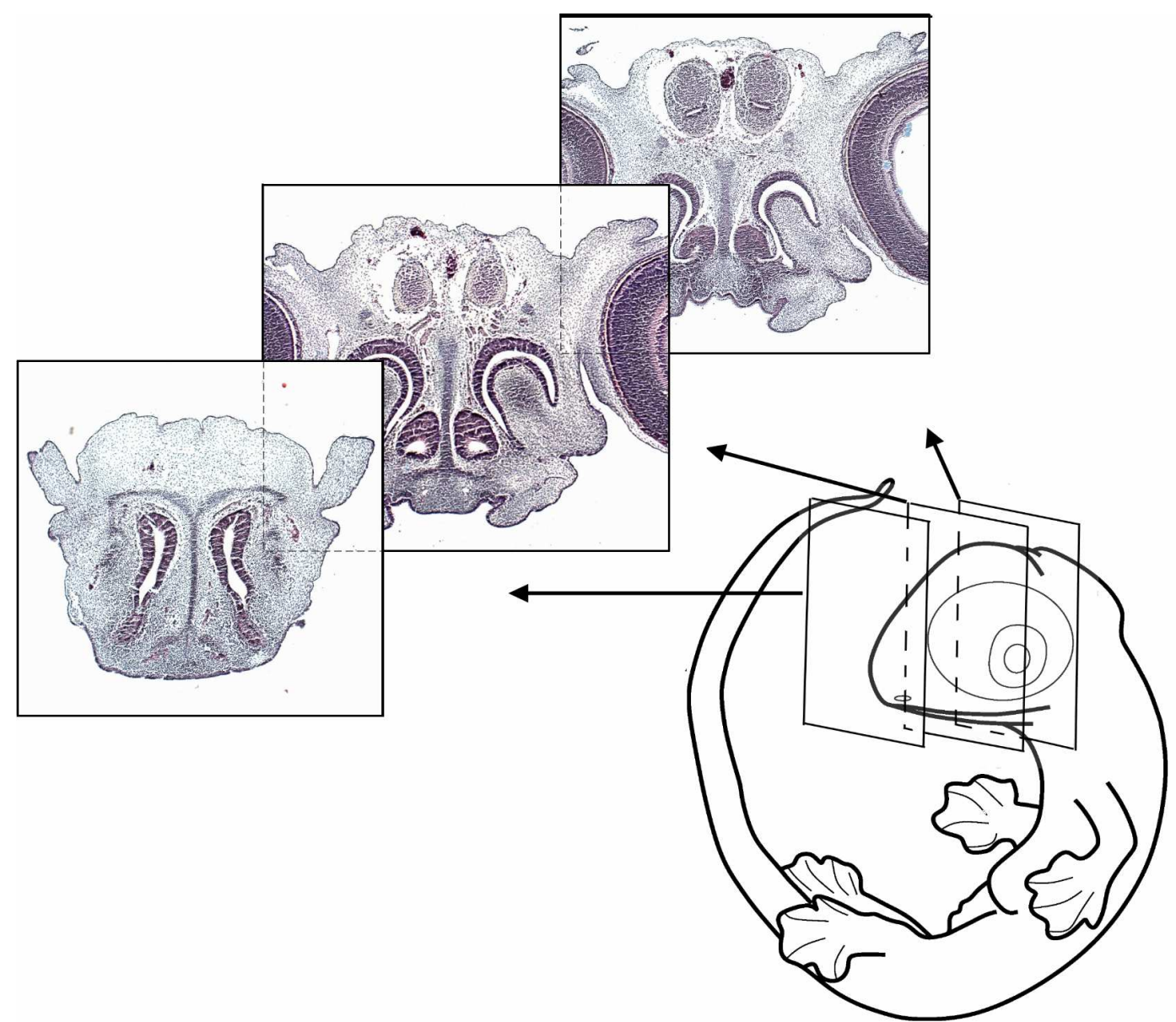

Рис. 3. Нюхові структури в різних ділянках голови ембріона L. viridis 34-ї стадї розвитку

Після виконання всіх цих кроків програма генерує тривимірну модель (рис. 4). Поверхня нюхових структур на моделі має нерівну, ступінчасту поверхню, яка утворюється внаслідок нерівномірного зминання серійних зрізів при різці на мікротомі. Цей недолік можна усунути в програмах із 3Dмоделювання. Важлива функція в програмі - можливість розглядати створену модель у різних площинах. Це дає змогу детально проаналізувати топографію, форму й відносні розміри досліджуваних структур. 


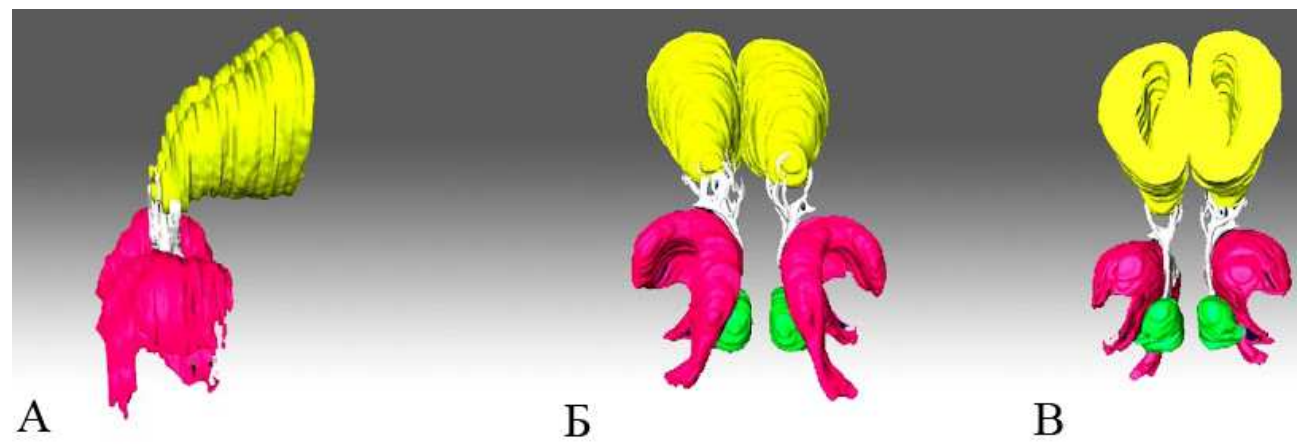

Рис. 4. Модель просторової реконструкиії периферичного відділу нюхового аналізатора ембріона L. viridis 34-ї стадї розвитку:

А - вигляд збоку; Б - вигляд спереду; В - вигляд ззаду

У програмі наявна функція, яка дає змогу демонструвати окремі елементи створеної моделі. Наприклад, можна залишити в просторовій моделі лише носову порожнину та вомероназальний орган (рис. 5). Це уможливлює окреме детальне вивчення морфології кожного елемента моделі.

Отримані моделі допомагають наочно оцінити й уявити характер розміщення нюхового органа в голові та оцінити розвиток структур в ембріогенезі (рис. 6).

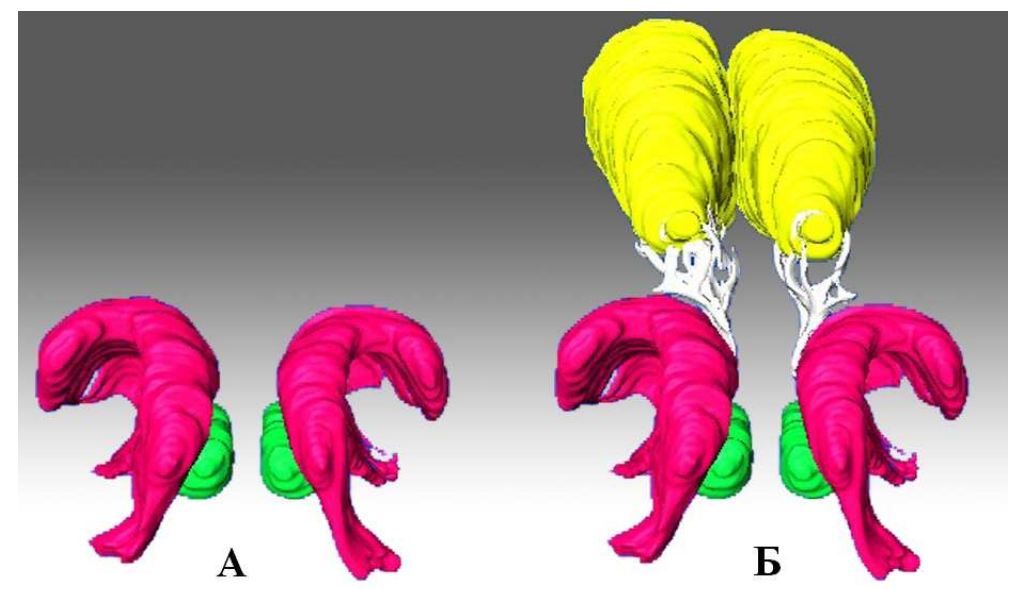

Рис. 5. Варіанти просторових моделей нюхового аналізатора ембріона L. viridis 34-ї стадії розвитку: А - сенсорний епітелій; Б - сенсорний епітелій, нюхові нерви та нюхові цибулини

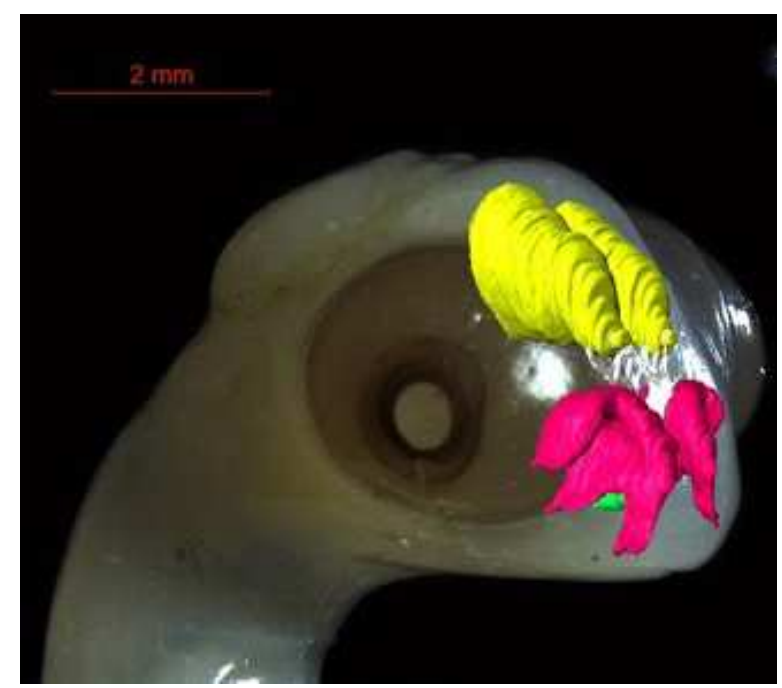

Рис. 6. Топографія нюхових структур ембріона L. viridis 34-ї стадї розвитку 
Висновки та перспективи подальшого дослідження. Виготовлення просторової реконструкції за допомогою програми Amira не вимагає значних затрат часу та спеціальної підготовки дослідника й підходить для будь-яких біологічних об'єктів. Створена просторова модель ембріона ящірки зеленої точно відображає всі морфологічні особливості нюхових структур. Модель зручна в користуванні, дає змогу переглядати та описувати всі морфологічні структури.

У подальших дослідженнях нами застосовуватиметься цей метод для опису розвитку нюхових структур на різних етапах онтогенезу риб і рептилій.

\section{Джерела та література}

1. Грубий В. Реконструкція нюхових мішків та суміжних структур голови ембріонів ящірки зеленої, Lacerta viridis (Reptilia, Squamata) / В. Грубий // Матеріали VII Міжнародної науково-практичної конференції студентів і аспірантів «Молода наука Волині: пріоритети та перспективи досліджень» : у 3 т. Т. 1. - Луцьк : Східноєвроп. нац. ун-т ім. Лесі Українки, 2014. - С. 43-45.

2. Комшук Т. С. Морфометрія та тривимірне зображення вентрикулярної системи мозку дитини 3,5 місяців / Т. С. Комшук, О. В. Корнійчук // Вісник проблем біології і медицини. - 2011. - Т. 2. - Вип. 2. - С. 127-130.

3. Потоцкая О. Ю. Трёхмерное компьютерное моделирование проэпикарда птиц на этапах эмбриогенеза / О. Ю. Потоцкая // Морфология. - 2007. - Т. 3, № 2. - С. 47-54.

4. Роскин Г. И. Микроскопическая техника / Г. И. Роскин, Л. Б. Левенсон. - М. : Сов. наука, 1957. -469 с.

5. Сілкіна Ю. В. Морфогенез просторової організації міркарду в філогенетичному аспекті : автореф. дис. ... канд. мед. наук : спец. 14.03.09 «Гістологія, цитологія, ембріологія» / Ю. В. Сілкіна. - Сімферополь, 2005. $-23 \mathrm{c}$.

6. Спосіб тривимірного реконструювання органів та структур / [І. Ю. Олійник, О. В. Корнійчук, Л. П. Лаврів, Н. В. Бернік] // Клінічна анатомія та оперативна хірургія. - Т. 10, № 1. - 2011. - С. 97-100.

7. Степанюк Я. В. Морфогенез сенсорного епітелію ящірки прудкої у Lacerta agilis (Reptilia, Squamata) / Я. В. Степанюк, О. М. Яригін, О. В. Титюк // Науковий вісник Миколаївського державного університету імені В. О. Сухомлинського (Біологічні науки). - Вип. 6.3 (113). - Миколаїв : МНУ ім. В. О. Сухомлинського, 2014. - С. 102-106.

8. Степанюк Я. В. Розвиток зовнішніх ніздрів та хоан у Lacerta agilis (Reptilia, Squamata) / Я. В. Степанюк, О. М. Яригін, О. В. Титюк // Науковий вісник Чернівецького університету. Біологія (Біологічні системи). - Т. 7. - Вип. 1. - Чернівці : Чернівец. нац. ун-т, 2015. - С. 129-132.

9. Твердохліб І. В. Просторова реконструкція біологічних об'єктів за допомогою комп'ютерного моделювання / І. В. Твердохліб // Морфологія. - 2007. - № 1. - С. 135-139.

10. Dufaure J. P. Table de développement du lézard vivipare, Lacerta (Zootoca) vivipara Jacquin / J. P. Dufaure, J. Hubert // Arch. Anat. Microsc. Morphol. Exp. - Vol. 50. - 1961. - P. 309-328.

11. Kralovec K. Development of the olfactory and vomeronasal organ in Discoglossus pictus (Dascoglossigae, Anura) / K. Kralovec, P. Zakova, V. Muzakova // Journal of morphology. - 2012. - P. 1-11.

12. Steedman H. F. Alcian blue 8GS: a new stain for mucin / H. F. Steedman // Quarterly journal of microscopical science. - Vol. 91. - 1950. - P. 477-479.

Тытюк Ольга, Грубый Владимир, Степанюк Ярослав, Ярыгин Александр. Пространственная реконструкция обонятельных структур Lacerta viridis при помощи компьютерного моделирования. Описан пример создания пространственной реконструкции структур обонятельного анализатора (носовой полости, вомероназального органа, обонятельных нервов, обонятельных луковиц) эмбриона ящерицы зеленой Lacerta viridis 34 стадии развития. Построение пространственной модели в программе Amira 5.0. создано на основе фотографий серийных гистологических срезов. Работа в программе состоит из подготовки микрофотографий, выравнивания исследуемых структур, выделения контуров структур и создания трехмерной модели. Изготовление пространственной реконструкции с помощью программы Amira не требует значительных затрат времени и специальной подготовки исследователя и годится для разных биологических объектов. Созданная пространственная модель эмбриона ящерицы зеленой точно отражает все морфологические особенности обонятельных структур. Модель является удобной в пользовании, позволяет просматривать и описывать все морфологические структуры.

Ключевые слова: эмбрион, пространственная реконструкция, обонятельный эпителий, вомероназальный орган.

Tityuk Olga, Grubiy Volodymyr, Stepanyuk Yaroslav, Yaryhin Oleksandr. Spatial Reconstruction of Olfactory Structures Lacerta viridis by Means of Computer Simulation. The example of creation of olfactory analyzer's 
spatial reconstruction (nasal cavity, vomeronasal organ, olfactory nerves, olfactory bulbi) of European green lizard's embryo at the $34^{\text {th }}$ stage of development is described. Construction of three-dimensional model in the program Amira 5,0 . is done on the basis of photos of serial histological sections. The work in the program consists of preparing of microphotos, levelling of structures under investigation, picking out the contours and creation of three-dimensional model. Doing spatial reconstruction with the help of Amira doesn't demand great time consumption and special training and is suited for all biological objects. The spatial model of lizard's embryo which was created exactly reflects all morphological particularities of olfactory elements. This model is easy to use, it allows to see and to describe all morphological structures.

Key words: embryo, spatial reconstruction, olfactory epithelium, vomeronasal organ.

Стаття надійшла до редколегії 05.10.2015 p.

УДК 593.16(477.41/42)

\section{Світлана Шевчук,} Людмила Васільєва

\section{Залежність чисельності гетеротрофних джгутикових центральної частини Українського Полісся від абіотичних факторів водного середовища}

Досліджено залежність чисельності гетеротрофних джгутикових центральної частини Українського Полісся від активної реакції водного середовища, умісту розчинених у воді кисню та органічних речовин. Установлено, що чисельність P. nitrophilus залежить від $\mathrm{pH}$ і розчинених у воді органічних речовин, A. tachyploon, B. globosus, G. truncata, P. apiculatus, $R$. nasuta - від розчиненого у воді кисню, а A. sigmoides, B. saltans, P. simplex - від розчинених у воді органічних речовин.

Ключові слова: гетеротрофні джгутикові, Українське Полісся, абіотичні фактори водного середовища.

Постановка наукової проблеми та її значення. Гетеротрофні джгутикові - найменш вивчений компонент водних біоценозів, хоча відома їх значна роль у функціонуванні останніх [7]. Ці протисти широко представлені серед усіх екологічних груп гідробіонтів і трапляються майже у всіх біотопах [3; 8]. Однак до сьогодні залишаються недостатньо вивченими питання екології гетеротрофних джгутикових, особливо аутекології.

Аналіз досліджень цієї проблеми. Більшість гетеротрофних джгутикових еврибіонтні, вони здатні існувати в широкому діапазоні екологічних факторів, таких як рН, солоність, температура та концентрація кисню, хоча для різних видів існують свої оптимуми [3]. Що стосується температури, то для кінетопластид, церкомонадид, хризомонади й евгленід оптимальна температура перебуває в межах від 15-26 ${ }^{\circ} \mathrm{C}$, тому в підлідний період їх чисельність зазвичай невисока [4]. Ця група протистів надає перевагу водоймам зі значеннями активної реакції водного середовища, що близькі до нейтральних [5]. Однак експериментальні дані та спостереження в природі вказали, що при значеннях $\mathrm{pH}$ у межах 3,4-4,0 успішно розвиваються комірцеві джгутикові, деякі кінетопластиди, хризофітові й частково евгленові [1]. Щодо розчиненого у воді кисню менш вимогливі бентосні та перифітонні джгутикові, а для дипломонадид кисень узагалі згубний. Достатньої кількості кисню потребують планктонні форми. Дані досліджень із культивування гетеротрофних джгутикових на середовищах різного складу засвідчують позитивний вплив розчинених органічних речовин на їх розвиток [3; 6]. Отже, накопичено дані щодо впливу абіотичних факторів на загальну чисельність гетеротрофних джгутикових, а не конкретних видів.

Мета роботи - 3'ясувати залежність чисельності гетеротрофних джгутикових центральної частини Українського Полісся від активної реакції водного середовища, умісту розчинених у воді кисню й органічних речовин.

(С Шевчук С., Васільєва Л., 2015 